\title{
INVENTORY OF BATS AND CULTURABLE PROTEOBACTERIA FROM CUEVA LAS ESCALERAS (TÁCHIRA, VENEZUELA): EVIDENCE OF POTENTIAL HUMAN HEALTH RISKS
}

\author{
Michel Mérida ${ }^{1}$, Gustavo Fermin ${ }^{2}$, Paolo Ramoni-Perazzi $^{3}$, and Mariana Muñoz-Romo ${ }^{3 *}$
}

\begin{abstract}
Caves are common roosts used by bats as permanent places for the settlement of stable colonies because caves are minimally affected by environmental conditions. Although Venezuela is a cave-rich country, with almost 700 caves formally described in the 2006 speleological inventory, these are still unknown in terms of their whole biological composition. Particular groups of animals have been described for some of these caves, but a list of culturable proteobacteria found inside any cave in the country has never been reported. During an inventory of bats in a small cave within a recreational park, we decided to perform a first look at the diversity of its bacteria and determine whether some of them have been reported as present in other caves, other environments, or even bats. Identification of bacteria was possible by amplifying and sequencing 16S rRNA genes from cultivated samples. Twenty-three clonal samples of bacteria from Cueva Las Escaleras (Pregonero, Táchira state, Venezuela) were obtained and analyzed. All but one sample belonged to the phylum Proteobacteria, and most of them have been reported to be potentially pathogenic to humans. From these identified bacteria, some (Achromobacter denitrificans, Proteus mirabilis, and Microvirgula aerodenitrificans) showed resistance to five widely used antibiotics. These results are important, as some bacteria found inside this cave may contaminate the water that flows from the cave and runs to the stream that crosses the park, forming ponds that surround lunch places. We detected a potential threat for public health at local and regional scales because many visitors use this water for drinking and washing hands and faces, and the cave itself is used for urination, defecation, and sexual activities.
\end{abstract}

\section{INTRODUCTION}

Venezuela is a cave-rich country. De Bellard Pietri (1966), in a review of 713 caves of the country, classified them according to geographical location and provided the following figures: 333 in the central region (north) of the country, 91 in eastern Venezuela, 227 in the west, 32 south to River Orinoco, and 30 in the insular region. There are no caves in the Llanos (central plains). The number of caves later increased to 989 as reported by the same author in the Atlas Espeleológico de Venezuela (de Bellard Pietri, 1969). However, only 650 Venezuelan caves were officially included in a recent speleological inventory (Urbani et al., 2006). The vast majority of caves in Venezuela originated from dissolution. In terms of their biodiversity, Venezuelan caves display a rich array of different species of animals, particularly insects and arachnids. Some caves can contain up to a hundred different animal taxa (Galán and Herrera, 2006); among vertebrates, Venezuelan caves host a wide range of fishes, birds, and bats, the latter mainly from the families Emballonuridae, Phyllostomidae, Mormoopidae, Desmodontidae, Natalidae, Furipteridae, Vespertilonidae, and Molossidae (Galán et al., 2008, 2009; Galán and Herrera, 2006). Caves are commonly used as roosts by bats, as they are places for the establishment of stable, long-lasting colonies of these gregarious mammals
(Kunz and Lumnsden, 2003). Conditions in caves are, in general, more stable than any other natural roost, since caves beyond the entrance are minimally affected by transient environmental conditions such as rain and wind.

Campbell et al. (2011) stated that many bacteria found in caves might be non-native species that have been transported into caves via water, air, or animals, and that their effect on the original environment is unknown. Despite Venezuela having a high density of known and unknown caves (Galán, pers. comm.), there is almost no literature regarding cave bacteria in this country. After a careful search for microbial studies in Venezuelan caves, we were able to find only one study (Barton et al., 2014). The authors analyzed the microbial activity of Roraima Sur Cave (Roraima Tepuy, Bolívar, Venezuela), working with DNA extracted from pooled samples of sediments from which $16 \mathrm{~S}$ rRNA amplicons were obtained, cloned, and subsequently sequenced. In endolithic bacterial communities at the entrance of the cave, an unusual community structure was characterized by the dominance of

\footnotetext{
${ }^{1}$ Department of Biology,

${ }^{2}$ Laboratorio de Biodiversidad y Variabilidad Molecular, Instituto Jardín Botánico de Mérida, and

${ }^{3}$ Laboratorio de Zoología Aplicada, Departamento de Biología, Facultad de Ciencias, Universidad de Los Andes, Mérida 5101, Venezuela.

* Corresponding Author: mariana@ula.ve
} 
Actinomycetales (mostly Pseudonocardia sp.) and Alphaproteobacteria (represented by nitrogen-fixing Beijerinkiaceae and Methylocella); deeper in the cave, the authors found that the microbial communities were dominated $(82-84 \%)$ by a unique clade of Ktedonobacterales (Chloroflexi). From the Archaea, dominance $(100 \%)$ of phylotypes from the Thaumarchaeota group was also demonstrated. This study involved an orthoquartzite cave, and it was based entirely on nonculture methods.

During an inventory of bats in a small cave within a recreational park, we decided to perform a first look at the diversity of culturable bacteria present in this cave. Although bats and other animals can be major sources of bacteria, humans also seem to be very frequent visitors based on the direct observation of human waste. Humans can be negatively affecting this cave, bringing bacteria on the soles of their shoes and by dumping feces, urine, blood, semen, and other organic waste. An important step to fully understanding the actual effect of bacteria on bats and other cave-organisms is to characterize the bacteria associated with this type of roost. The goal of this study was to determine what culturable bacteria might be present in Cueva Las Escaleras, and to provide a list of bats roosting in this cave. Moreover, if humans are frequent visitors to this cave, we would initially expect to find that the presence or absence of bacteria species showing association to humans. Finally, it would be important to determine whether some bacteria present in this cave have been reported as potentially dangerous or pathogenic.

\section{Methods}

\section{STUdy Site}

The cave is located within a recreational park called Las Escaleras, and it is known as Cueva Las Escaleras $\left(8^{\circ} 00^{\prime} 18.8^{\prime \prime}\right.$ $\mathrm{N}, 71^{\circ} 43^{\prime} 41.8^{\prime \prime} \mathrm{W}, 1320$ masl). The cave is found approximately $4 \mathrm{~km}$ southeast of the town of Pregonero, Municipio Uribante, Estado Táchira, Venezuela (Fig. 1). The vegetation of the area is mainly that of human-disturbed habitats, followed by open savanna of oligotrophic origin and small patches of secondary forest surrounding rivers and creeks (Ramoni-Perazzi et al. 2014). Mean temperature of the study site is $20{ }^{\circ} \mathrm{C}$ (Molina-Chacón, 1983). Annual precipitation averages $1636.9 \mathrm{~mm}$ (INAMEH, 2008), occurring in a unimodal pattern, with a period of water deficit from January to March, and a period of water availability the rest of the year, with maxima in July and August (Molina-Chacón 1983). The cave is about $38 \mathrm{~m}$ long and it is divided in two chambers, the second of which is then divided in two, forming a Y. The cave is frequently visited by people.

\section{Sampling Procedure: Bats}

Bats were captured to determine the inventory of bats living within the cave. All sampling protocols were performed following guidelines of the American Society of Mammalogists for capture, handling, and care of mammals (Sikes et al.
2011). Bats were captured using both hand nets and $12 \mathrm{~m}$ long, $38 \mathrm{~mm}$ mesh, 50 denier, four-shelf mist nets (Avinet, Dryden, New York, USA; Kunz et al. 2009) between 11:00 and 16:00 h. All individuals were released in the study site immediately after their species was determined.

\section{Sampling and Collection of Bacteria}

During three field trips in February 2010 the cave was sampled for bacteria. The floor, ceiling, and walls of the cave were scratched with syringes, and the resulting dust directly streaked onto Petri dishes containing agarized Luria-Bertani rich medium and fungicides (see below). To collect airborne bacteria, four Petri dishes, one per corner of the sampled area at the beginning of the left side of the Y, were left open during the time required, about $45 \mathrm{~min}$, for cave sampling. Using a cooler, inoculated dishes were brought to the lab, where they were incubated at a constant temperature of $37{ }^{\circ} \mathrm{C}$ under aerobic conditions up to $72 \mathrm{~h}$. To avoid fungal growth, agarized plates were amended with Terraclor $(860 \mu \mathrm{g} / \mathrm{mL})$ and Benlate $(200 \mu \mathrm{g} / \mathrm{mL})$. Terraclor is a $75 \%$ pentachloronitrobenzene (PCNB) soil fungicide (Chemtura, Middlebury, CT), while Benlate is the $50 \%$ commercial product of the systemic fungicide benomyl (Dupont, Wilmington, DE). Selected clones, based on shape, size, and color were kept in stabs and at $-80{ }^{\circ} \mathrm{C}$ for long-time storage.

\section{Bacteria Cultivation and Purification}

Inoculated dishes were incubated for 24 to 72 hours after collection, and then kept under aerobic conditions at $4{ }^{\circ} \mathrm{C}$ until use. Based on macromorphological differences among colonies, such as size, color, elevation, border, and shape, selected colonies were streaked again for further purification. Colonies were reisolated in the same medium and observed under the microscope after Gram staining to check for purity and Gram's reaction (Gerhardt et al., 1994). Five isolated, purified clones from each original colony were stored at $-80{ }^{\circ} \mathrm{C}$ and used to streak master Petri dishes, one for every cave part: soil, walls, ceiling, and air.

\section{Phenotypic Characterization of Bacteria}

Isolated colonies of all sampled bacteria were described in terms of color, shape, texture, borders, opacity, and other properties. Additionally, all samples were tested by Gram's reaction and the $\mathrm{KOH}$ test. Samples proven to be pure were subjected to further characterization using an API gallery battery of tests (API20E). Assay for antibiotic resistance was carried out in the same LB medium supplemented, in separate plates, with ampicillin $(50 \mu \mathrm{g} / \mathrm{ml})$, streptomycin $(50 \mu \mathrm{g} / \mathrm{ml})$, gentamicin $(50 \mu \mathrm{g} / \mathrm{ml})$, kanamycin $(30 \mu \mathrm{g} / \mathrm{ml})$, or tetracycline $(12.5 \mu \mathrm{g} / \mathrm{ml})$.

\section{Amplification of the 16S RRNA Gene by Colony PCR}

One day before the amplification of the 16S rRNA gene by $\mathrm{PCR}$, each individual colony was reisolated as before and 


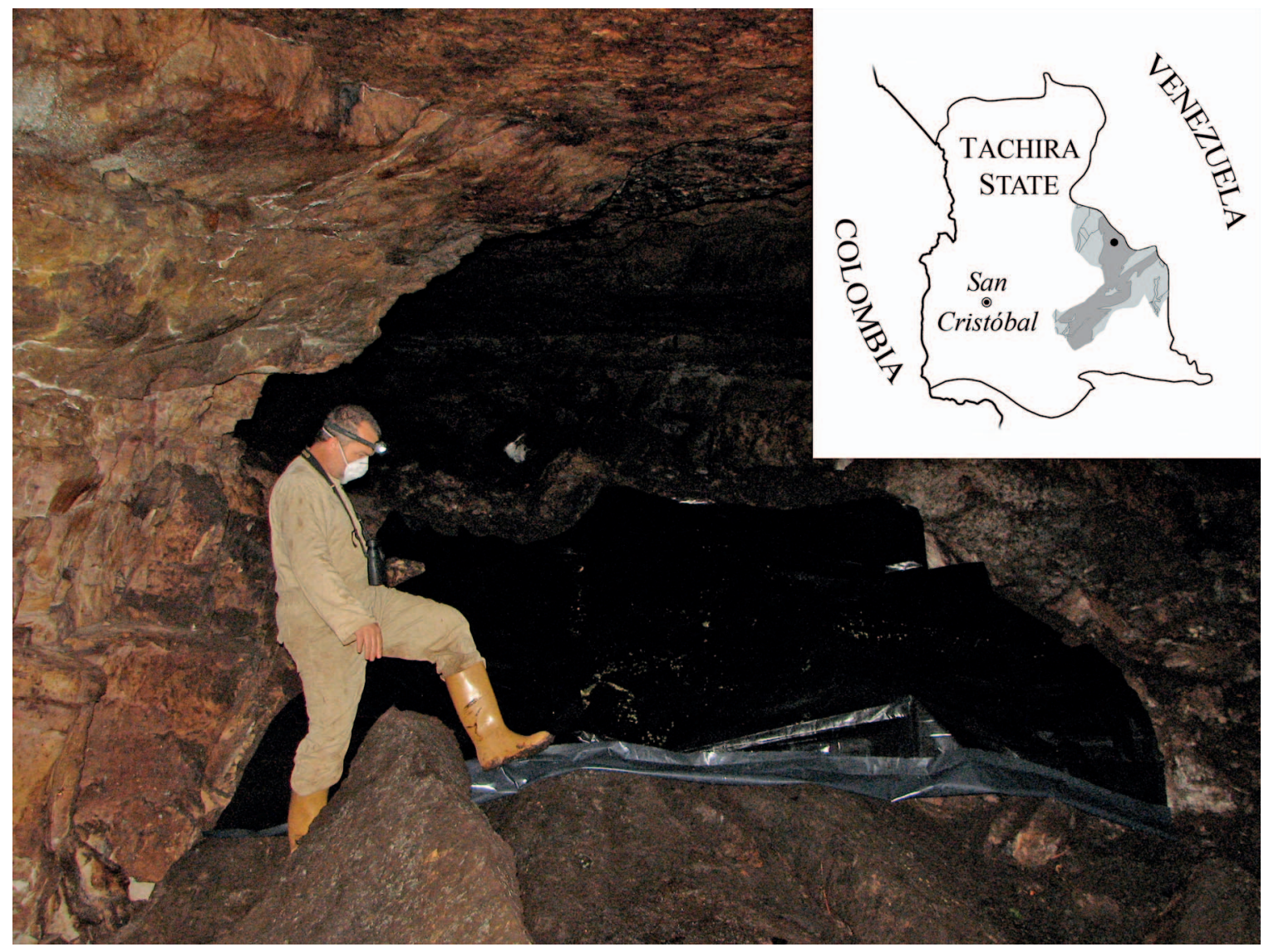

Figure 1. Inside Cueva Las Escaleras, Pregonero, Municipio Uribante, Táchira state. Top-right: Location of the municipality and the distribution of its geologic units following Garrity et al. (2006). The Lower Cretaceous Río Negro Formation, which is composed of limestone, shale, calcareous sandstone, and conglomerate, is highlighted in darker gray.

grown overnight at $37^{\circ} \mathrm{C}$. Fresh cultures were always used in all amplification protocols. Reaction mixtures for PCR amplification of the 16S rRNA gene (Dekio et al., 2005) consisted of $10 \mu \mathrm{L}$ of the $1 \mathrm{X}$ GoTaq Green master mix (Promega, Madison, WI) supplemented with the universal primers 27F: 5'AGAGTTTGATCCTGGCTCAG3' and 1492R: 5'GGTTACCTTGTTACGACTT3' (Batison et al. 2009). Once the reaction mixture was prepared, the colony to be tested was gently touched with a micropipette tip and washed in the reaction mixture tube. PCR amplification was performed according to the following program: an initial denaturation step at $95^{\circ} \mathrm{C}$ for $10 \mathrm{~min}$, followed by 30 cycles of denaturation at $94{ }^{\circ} \mathrm{C}$ for $45 \mathrm{sec}$, annealing at $51{ }^{\circ} \mathrm{C}$ for $45 \mathrm{sec}$, and extension at $72{ }^{\circ} \mathrm{C}$ for $90 \mathrm{sec}$. A final extension step at 72 ${ }^{\circ} \mathrm{C}$ for 10 min was also included (Batisson et al., 2009; Dekio et al., 2005). Amplification products' quantity, quality, and size were checked by agarose gel electrophoresis and digitally recorded as previously recommended (Sambrook and Russell, 2001). Single, clear bands were salt and ethanol-precipitated and sent for sequencing, both strands, without further purification to the sequencing facility of Instituto Venezolano de Investigaciones Científicas (IVIC, Caracas). All amplicons were sequenced with the amplification primers cited before plus internal primers directed towards the ends of the amplicon as reported by Rogall et al. in 1990 (Pa:5'AGAGTTTGATCCTGGCTGAG-3', and Pe:5'CCGTCAATTCTTTTGAGTTT- ${ }^{\prime}$ ). In general, each amplicon produced four to six sequence reads of high quality; a few produced only two workable reads.

\section{BioInformatics ANALYSIS}

A contig for every sequence per sample was obtained using all derived reads per amplicon with BioEdit (Hall, 1999), and the contig compared with equivalent sequences available in public databases (GenBank) by BLAST using default parameters (Altschul et al., 1990). An a priori criterion of quality of similarity of $98 \%$ or higher (Pei et al. 2010, Stackebrandt and Ebers 2006) was used as the threshold value of success and identification if the query coverage was also equal to or higher than $98 \%$. An a posteriori criterion of higher than $99 \%$ similarity with $100 \%$ coverage was set later. Moreover, sequences identified this way were also subjected to other two criteria of identity by similarity: best BLAST species matches were corroborated with the RDP's Classifier 
M. Mérida, G. Fermin, P. Ramoni-Perazzi, and M. Muñoz-Romo

Table 1. Identity of the bacteria sampled at Cueva Las Escaleras (Pregonero, Táchira, Venezuela) based on the sequencing and analysis of the $16 \mathrm{~S}$ rRNA gene.

\begin{tabular}{lclc}
\hline Sample $^{\text {a }}$ & Contig Length, nt & \multicolumn{1}{c}{ Best Candidate Species } & GenBank (this Work) \\
\hline M1, W & 1413 & Pseudomonas sp. & KT792722 \\
M2, W & 1411 & Pseudomonas sp. & KT792723 \\
M3, W & 1402 & Achromobacter denitrificans & KT792724 \\
M4, W & 1407 & Pseudomonas monteilii & KT792725 \\
M5, S & 1420 & Citrobacter freundii & KT792726 \\
M6, S & 1407 & Pseudomonas monteilii & KT792727 \\
M7, S & $\ldots$ & Excluded (sequences too short) & $\ldots$ \\
M8, S & 1409 & Pseudomonas putida & KT792729 \\
M9, S & 1412 & Escherichia coli & KT792730 \\
M10, S & 1457 & Pseudomonas putida & KT792731 \\
M11, S & 1412 & Pseudomonas xiamenensis & KT792732 \\
M12, S & 1412 & Raoultella electrica & KT792733 \\
M13, S & 1441 & Klebsiella oxytoca & KT792734 \\
M14, S & 1417 & Klebsiella oxytoca & KT792735 \\
M15, S & 817 & Proteus mirabilis & KT792736 \\
M16, A & 1462 & Proteus mirabilis & KT792737 \\
M17, A & 1414 & Proteus mirabilis & KT792738 \\
M18, A & 916 & Proteus mirabilis & KT792739 \\
M19, A & 866 & Proteus vulgaris & KT792740 \\
M20, A & 920 & Microvirgula aerodenitrificans & KT792741 \\
M21, A & 877 & Providencia rettgeri & KT792742 \\
M22, A & 850 & Proteus mirabilis & KT792743 \\
M23, A & 1424 & KT792728 \\
\hline
\end{tabular}

${ }^{a}$ S, soil; W, wall and ceiling; A, air

(Wang et al., 2007) and with the EzBioCloud (Kim et al., 2012) algorithms. In Table 1, accession numbers for the bacteria molecularly analyzed in this work is provided, along with their putative identity in those cases were the three criteria of identification were concordant (all but one case). Finally, alignments were performed using CLUSTALX2 (Larkin et al., 2007), and relatedness among bacteria analyzed by neighbor-joining using MEGA6 (Tamura et al., 2013) with 1000 replicates under the K2P model.

\section{Results}

Cueva Las Escaleras is a recreational place for the inhabitants and visitors of the town of Pregonero, and humans leave remnants of burnt logs, toilet paper, cans, plastic bottles and residues, feces, used condoms, and female hygiene products that were observed during our sampling visits. These remains become scarcer as light diminishes deeper inside the cave to the place where the bacterial samples were taken, close to a bat colony. We were able to recover bacteria from the scratched ceiling, walls, and floor of the cave (Fig. 2). Plates left open to the air, a third of all samples, also yielded bacteria. In total, we worked with twenty-two isolated and well molecularly identified bacteria. Colony PCR allowed for the reliable identification of the samples selected, which is why we changed our a priori criterion of identification to make it the more stringent $100 \%$ coverage and more than $99 \%$ similarity. Only two samples (M1 and M2), with contigs derived from five and six independent sequencing reactions (1413 and $1411 \mathrm{nt}$ long, respectively, but identical between them) provided reliable information only to the genus level (97\% similarity to Pseudomonas spp. with a coverage of 100\%). This sample might represent a new Pseudomonas species. Additional biochemical tests not shown were concordant with the molecular identity of the bacteria subjected to this analysis, which is summarized in Table 1 and Figure 3. All but one of the bacterial samples belongs to the phylum Proteobacteria (two to the $\beta$ group, and nineteen to the $\gamma$ group); the other bacterial species was Paenibacillus lactis (phylum Firmicutes).

Surprisingly, all bacteria were resistant to ampicillin, and thirteen of the samples were resistant to at least one of the other antibiotics tested; three bacterial samples (Achromobacter denitrificans, Proteus mirabilis, and Microvirgula aerodenitrificans) were resistant to the five antibiotics tested in independent assays (Table 2).

Five species of bats were identified inside Cueva Las Escalerass: the large fruit-eating bat (Artibeus amplus), the short-tailed fruit bat (Carollia perspicillata), the common vampire bat (Desmodus rotundus), the hairy-legged vampire bat (Diphylla ecaudata), and the Luis Manuel's tailless bat (Anoura luismanueli) (Fig. 4).

Journal of Cave and Karst Studies, December 2016•177 

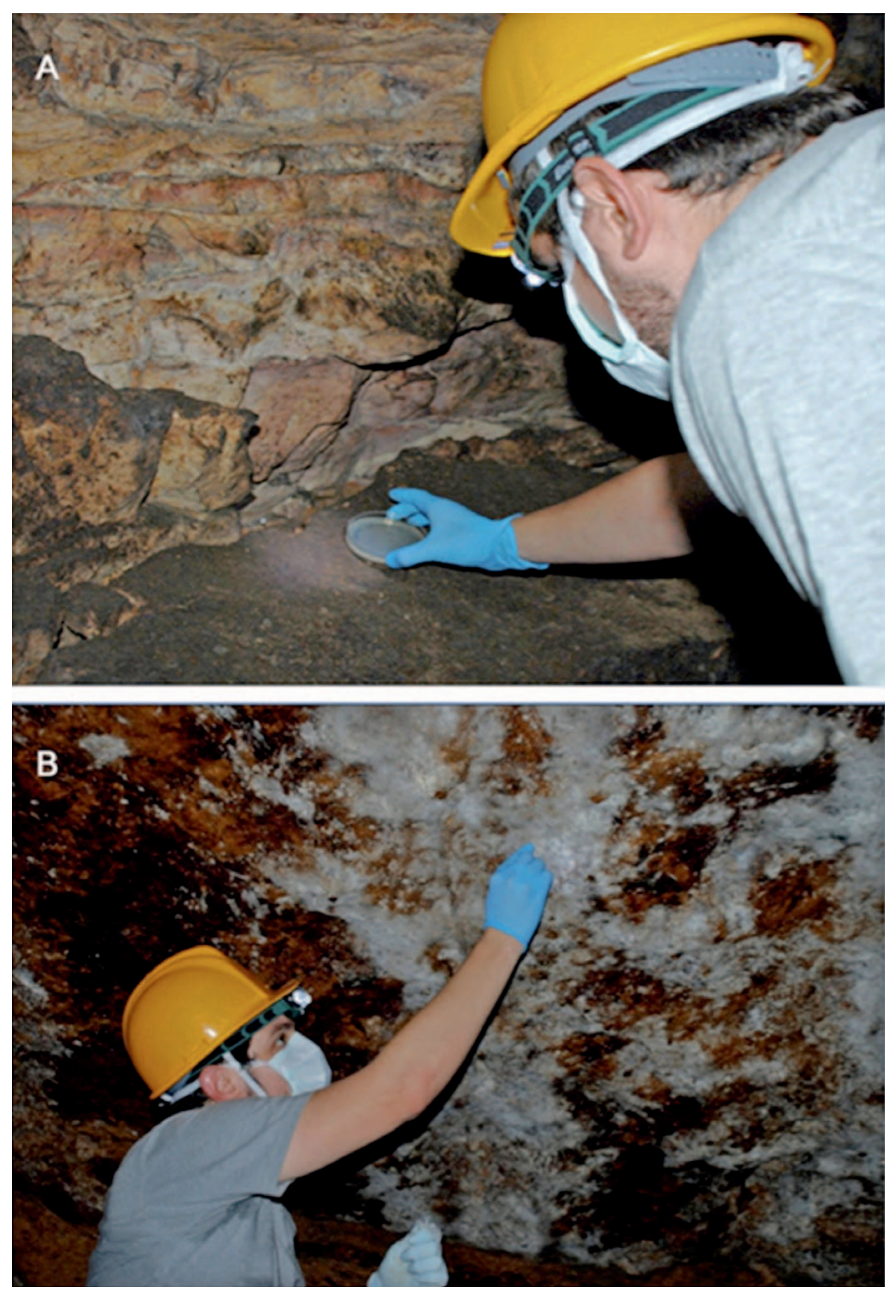

Figure 2. Bacteriological sampling in Cueva Las Escaleras for airborne bacteria (A) and by wall and ceiling scratching (B).

\section{DISCUSSION}

As an initial attempt to characterize the bacterial flora present in Cueva Las Escaleras, a molecular approach based on the amplification and sequencing of the 16S rRNA bacterial gene was used in this study, taking as a cutoff value of identification more than 99\% similarity between our sequences and those reported at public databases. Results were concordant by three identification molecular, independent criteria, including the unassigned Pseudomonas sp. reported here.

As reported elsewhere, the main group of bacteria found in caves is the Proteobacteria, particularly when they are identified by molecular tools; Actinobacteria, however, constitute the bacteria most frequently found in these environments, which seem to represent a habitat particularly favorable for members of this group (Jurado et al., 2010). All but one of the bacteria identified in this work are Proteobacteria.

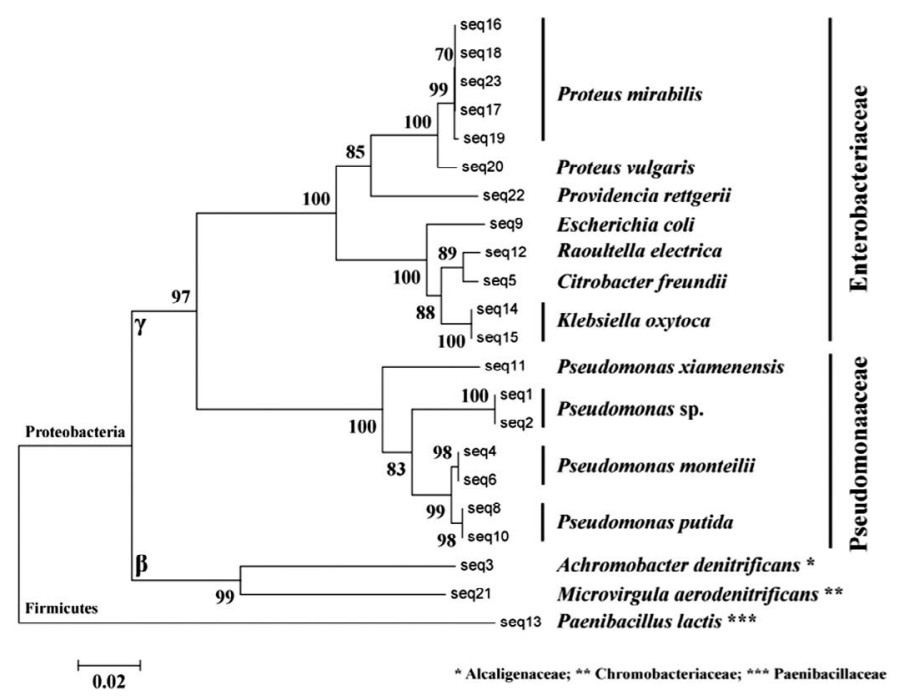

Figure 3. Cladogram of the bacteria of Cueva Las Escaleras reported in this work after running MEGA6 (Tamura et al., 2013) by neighbor-joining with 1000 replicates under the $\mathrm{K} 2 \mathrm{P}$ model.

Almost all the bacteria samples molecularly identified in this study (Table 1) are recognized as potential human pathogens. Achromobacter denitrificans, which is a ubiquitous bacteria commonly found in soil and aquatic environments, has been reported to cause pneumonia in humans (Aundhakar et al., 2014); Citrobacter freundii, although a rare opportunistic nosocomial pathogen, is able to cause neonatal meningitis among other illnesses (Badger et al., 1999; Chen et al., 2002; Tschäpe et al., 1995); Escherichia coli, a very well know pathogen, has also been reported in other caves visited by humans, like the Lascaux Cave in France (Bastian et al., 2010), six caves in northern Alabama and northwestern Georgia, USA (Campbell et al. 2011), and diverse caves in Mizoram in northeast India (De Mandal et al., 2014) to name a few; Klebsiella oxytoca, which may cause colitis and sepsis, can be present in human stools (Högenauer et al., 2006); Microvirgula aerodenitrificans, a denitrifying bacteria originally isolated from activated sludge (Cleenwerk et al., 2003; Patureau et al., 1998), although not deemed as pathogenic, can also be found associated with bacteremia in immunosupressed patients (Murphy et al., 2012); Proteus mirabilis, widely distributed in soil and water is responsible for approximately 90\% of all Proteus infections in humans, particularly of the urinary tract; and Providencia rettgerii, also common in soil and water, can cause opportunistic infections in humans, including the urinary tract and eyes, as well as traveler's diarrhea, abdominal pain, fever, and vomiting (Yoh et al., 2005). Among the Pseudomonas species (Anzai et al., 2000) found in Cueva Las Escaleras, we were able to identify by $16 \mathrm{~S}$ rRNA sequencing $P$. xiamenenesis and from the putida group, $P$. putida and $P$. monteilii. The latter was originally isolated from clinical samples including bronchial aspirates, and it is believed to be a rare opportunistic pathogen or colonizer 
M. Mérida, G. Fermin, P. Ramoni-Perazzi, and M. Muñoz-Romo

Table 2. Antibiotic resistance shown by isolated bacteria sampled at Cueva Las Escaleras (Pregonero, Táchira, Venezuela).

\begin{tabular}{lll}
\hline Sample & \multicolumn{1}{c}{ Best Candidate Species } & Antibiotic Resistance $^{\mathrm{a}}$ \\
\hline M1 & Pseudomonas sp. & Amp \\
M2 & Pseudomonas sp. & Amp \\
M3 & Achromobacter denitrificans & Amp, Str, Gnt, Kan, Tet \\
M4 & Pseudomonas monteilii & Amp \\
M5 & Citrobacter freundii & Amp \\
M6 & Pseudomonas monteilii & Amp, Tet \\
M7 & Excluded in sequencing & Amp \\
M8 & Pseudomonas putida & Amp \\
M9 & Escherichia coli & Amp, Str, Gnt, Kan \\
M10 & Pseudomonas putida & Amp \\
M11 & Pseudomonas xiamenensis & Amp \\
M12 & Raoultella electrica & Amp, Tet \\
M13 & Paenibacillus lactis & Amp, Str, Gnt, Kan \\
M14 & Klebsiella oxytoca & Amp, Gnt, Kan, Tet \\
M15 & Klebsiella oxytoca & Amp, Tet \\
M16 & Proteus mirabilis & Amp, Tet \\
M17 & Proteus mirabilis & Amp, Str, Gnt, Kan, Tet \\
M18 & Proteus mirabilis & Non tested \\
M19 & Proteus mirabilis & Amp, Kan, Tet \\
M20 & Proteus vulgaris & Amp, Kan, Tet \\
M21 & Microvirgula aerodenitrificans & Amp, Str, Gnt, Kan, Tet \\
M22 & Providencia rettgeri & Amp, Gnt, Kan, Tet \\
M23 & Proteus mirabilis & Not tested
\end{tabular}

${ }^{\text {a }}$ Determined by lack of growth after $24-48 \mathrm{~h}$ of incubation under aerobic conditions at $37^{\circ} \mathrm{C}$ on solid LB media containing ampicillin (Amp) $50 \mu \mathrm{g} / \mathrm{ml}, \mathrm{streptomycin}$ (Str) 50 $\mu \mathrm{g} / \mathrm{ml}$, gentamicin (Gnt) $50 \mu \mathrm{g} / \mathrm{ml}$, kanamycin (Kan) $30 \mu \mathrm{g} / \mathrm{ml}$, or tetracycline (Tet) $12.5 \mu \mathrm{g} / \mathrm{ml}$

(Elomari et al., 1997). We found another pseudomonad that is closely related to $P$. pseudoalcaligenes, but a similarity of $97 \%$ does not allow conclusion about specific identity. Two different samples were identical among themselves at the sequence level.

Another bacterium found in this study, a Firmicutes, was Paenibacillus lactis, an organism originally isolated from raw and heat-treated milk (Schedelman et al., 2004), but that can also be found in bacterial communities in environmental samples (da Mota et al., 2005). We found no reference dealing with pathogenicity to humans of this bacterium or the recently described Raoultella electrica (Kimura et al., 2014).

We contend that the bacteria reported are not indigenous to the cave but carried into it by humans because, first, humans leave man-made litter in the cave along with feces, urine, menstrual blood, and semen; second, the bacteria found in other caves, including some with recreational uses but with better visiting strategies and cave protection, do not resemble the bacteria we report in that the ones present in Las Escaleras are almost all pathogenic for humans; third, bacteria isolated from caves as their indigenous habitats and considered pathogenic mostly belong to the Actinobacteria (particularly those of the genera Nocardia, Mycobacterium, Gordonia, Rhodococcus, and Streptomyces; Jurado et al., 2010), while others are members of the Alphaproteobacteria groups such as Inquilinus limosus or Aurantimonas spp., members of the genus Afipia, or Staphylococcus aureus, none of them found in this work; and finally, although not completely conclusive, of forty-two species of bacteria in a catalog of bacteria (González-Quiñones et al., 2014) found on the skin of Sturnira lilium and S. bogotensis bats (Chiroptera: Phyllostomidae), only two (E. coli and C. freundii) were also present in this cave.

Bats found inside Cueva Las Escaleras are using it as a day roost, since all of them were captured during their daylight resting period. Two of the species of bats (Carollia perspicillata and Desmodus rotundus) are common (Linares, 1987) and widely distributed in Venezuela (Linares, 1998). C. perspicillata is the most common and widespread bat species in Venezuela (Linares 1998). Since it feeds on at least fifty different fruits, it is an important seed disperser in many moist evergreen and dry deciduous forests, usually below 1,000 masl (Fleming, 1988). C. perspicillata roosts in caves, forming groups of no more than one hundred individuals. The vampire bat (D. rotundus) is a common species that frequently uses caves as roosts. It forms stable, long-lasting colonies.

The other three species (Artibeus amplus, Diphylla ecaudata, and Anoura luismanueli) are more geographically restricted and less common, and all three might need caves as primary roosts (Handley, 1987; Linares, 1998). The large fruit-eating bat (A. amplus) is a species commonly found in caves (Handley, 1987; Ruiz-Ramoni, 2010), and its large

Journal of Cave and Karst Studies, December 2016 • 179 


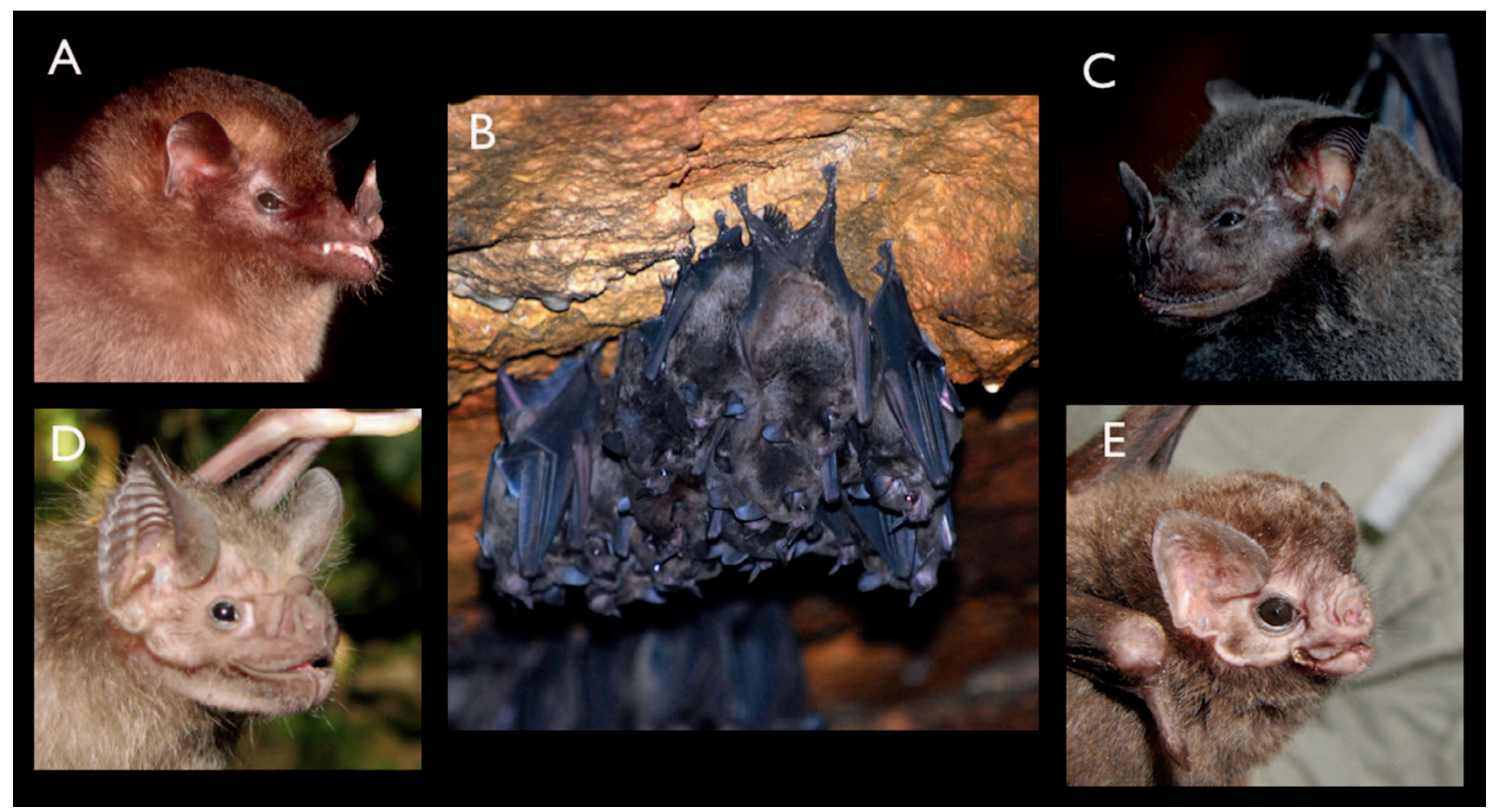

Figure 4. Bats captured and identified at the study site, Cueva Las Escaleras, Táchira state, Venezuela. A, Anoura luismanueli; B, Carollia perspicillata; C, Artibeus amplus; D, Desmodus rotundus; E, Diphylla ecaudata.

colony in Las Escaleras cave is a stable group throughout the year (Ruiz-Ramoni, 2010). Luis Manuel's tailless bat (Anoura luismanueli) is an uncommon species of nectarivorous bat from Los Andes, and it is also found in caves. The hairylegged vampire bat (D. ecaudata) is the only one of three extant species of vampire bats that feeds exclusively on the blood of birds. It is a rare species, one of the few species of monogamous bats (and mammals), and is monotypic (Linares, 1998). Bat diversity in this small cave is remarkable.

Although the presence of these bats in the cave could suggest that they are not being adversely affected by the potentially pathogenic bacteria, it is of utmost importance to stop using it as a recreational room for human activities. It is still unknown whether potentially pathogenic bacteria could cause sickness or death of bats. Although bats are still living there despite these bacteria, the natural environment in this cave has been affected, and it is not possible to determine its consequences without further research. For example, potentially pathogenic bacteria might be affecting vampire bats (Desmodus rotundus), because this species commonly walks on the ground, especially after a meal. Vampire bats might not be able to fly when they finish feeding on blood, and they usually walk or run on the ground when returning to their roosts. The contact of their bodies with the contaminated soil could affect their own lives and that of other members of the colony due to allogrooming.

Protecting a cave from antropogenic disturbances is of utmost importance not only to preserve its biodiversity, but also as a source of discoveries. For example, observations in this particular cave resulted in the first and only report of leucism, a pigmentation disorder, in A. amplus (Muñoz-Romo et al., 2014), and also the discovery that folivory was a permanent phenomenon in some species (Ruiz-Ramoni et al., 2011); it had been considered a rare and occasional phenomenon since its discovery (van der Pijl, 1957).

As stated by Galán and Herrera (2006), it is imperative to protect karst regions, including the conservation of their species, many of which are unique and hence invaluable in terms of the biodiverse richness of Venezuela and the planet. Also, the findings of diverse vertebrate fossils in Venezuelan caves, including from various bats (Rincón, 2004), adds to the importance of these particular environments for the understanding not only of our present biodiversity, but also that of our distant past, as well as of the ecological requirements of an important group of bats.

We consider the bacteriological status of Cueva Las Escaleras a potential public health threat because water from the cave floor is running directly into the stream that serves this recreational park. Furthermore, bacteria found in this work are also present in the air, making more worrisome their potential health risks to humans. The bacteria assemblage derived from human presence and activities in caves might be affecting the natural bacterial communities in ways that are not yet completely understood (Campbell et al., 2011). 


\section{ACKNOWLEDGMENTS}

We are grateful to Damián Ruiz-Ramoni and Luisa M. Otero for invaluable field assistance. We are also grateful to the Associate Editor and anonymous reviewers for helpful recommendations to improve the final version of this manuscript. This research was partially supported by the CDCHT (Universidad de Los Andes) project C-1681-09-01-B, and by the resources of Laboratorio de Biodiversidad $\mathrm{y}$ Variabilidad Molecular.

\section{REFERENCES}

Altschul, S.F., Gish, W., Miller, W., Myers, E.W., and Lipman, D.J., 1990, Basic local alignment search tool: Journal of Molecular Biology, v. 215, p. 403-410. doi:10.1016/S0022-2836(05)80360-2.

Anzai, Y., Kim, H., Park, J.-Y., Wakabayashi, H., and Oyaizu, H., 2000, Phylogenetic affiliation of the pseudomonads based on 16S rRNA sequence: International Journal of Systematic and Evolutionary Microbiology, v. 50, p. 1563-1589. doi:10.1099/00207713-50-4-1563.

Aundhakar, S.C., Mane, M.B., Bharadiya, A.A., and Pawar, S.K., 2014, Watch out! Pneumonia secondary to Achromobacter denitrificans: Annals of Medical \& Health Sciences Research, v. 4, Suppl 1, p. S22-S24. doi:10. 4103/2141-9248.131700.

Badger, J.L., Stins, M.F., and Kim, K.S., 1999, Citrobacter freundii invades and replicates in human brain microvascular endothelial cells: Infection and Immunity, v. 67 , p. $4208-4215$.

Barton, H.A., Giarrizzo, J.G., Suarez, P., Robertson, C.E., Broering, M.J., Banks, E.D., Vaishampayan, P.A., and Venkateswaran, K., 2014, Microbial diversity in a Venezuelan orthoquartzite cave is dominated by the Chloroflexi (Class Ktedonobacterales) and Thaumarchaeota Group I.1c: Frontiers in Microbiology, v. 5, Article 615, 14 p. doi:10.3389/fmicb. 2014.00615.

Bastian, F., Jurado, V., Nováková, A., Alabouvette, C., and Saiz-Jimenez, C., 2010, The microbiology of Lascaux Cave: Microbiology, v. 156, p. 644 652. doi:10.1099/mic.0.036160-0.

Batisson, I., Crouzet, O., Besse-Hoggan, P., Sancelme, M., Mangot, J.-F., Mallet, C., and Bohatier, J., 2009, Isolation and characterization of mesotrione-degrading Bacillus sp. from soil: Environmental Pollution, v. 157, p. 1195-1201. doi:10.1016/j.envpol.2008.12.009.

Campbell, J.W., Watson, A., Watson, C., Ball, H., and Pirkle, R., 2011, Escherichia coli, other coliform, and environmental chemoheterotrophic bacteria in isolated water pools from six caves in northern Alabama and northwestern Georgia: Journal of Cave and Karst Studies, v. 73, p. 75-82. doi:dx.doi.org/10.4311/jcks2009mb0131.

Chen, Yen-Hsu., Wong, Wing-Wai, Fung, Chang-Phone, Yu, Kwok-Woon, and Liu, C.Y., 2002, Clinical features and antimicrobial susceptibility trends in Citrobacter freundii bacteremia: Journal of Microbiology, Immunology and Infection, v. 35, p. 109-114.

Cleenwerck, I., De Wachter, M., Hoste, B., Janssens, D., and Swings, J., 2003, Aquaspirillum dispar Hylemon et al. 1973 and Microvirgula aerodenitrificans Patureau et al. 1998 are subjective synonyms: International Journal of Systematic and Evolutionary Microbiology, v. 53, p. $1457-$ 1459. doi:10.1099/ijs.0.02675-0.

da Mota, F.F., Gomes, E.A., Paiva, E., and Seldin, L., 2005, Assessment of the diversity of Paenibacillus species in environmental samples by a novel rpoB-based PCR-DGGE method: FEMS Microbiology Ecology, v. 53, p. 317-328. doi:dx.doi.org/10.1016/j.femsec.2005.01.017.

de Bellard Pietri, E., 1966, Las cavernas más importantes de Venezuela: Boletín de la Academia de Ciencias Físicas, Matemáticas y Naturales, v. 26, p. 104-111.

de Bellard Pietri, E., 1969, Atlas Espeleológico de Venezuela: Boletín de la Academia de Ciencias Físicas, Matemáticas y Naturales, v. 29, p. 1-171.

Dekio, I., Hayashi, H., Sakamoto, M., Kitahara, M., Nishikawa, T., Suematsu, M., and Benno, Y., 2005, Detection of potentially novel bacterial components of the human skin microbiota using culture independent molecular profiling: Journal of Medical Microbiology, v. 54, p. 12311238. doi:10.1099/jmm.0.46075-0.
De Mandal, S., Sanga, Z., and Nachimuthu S.K., 2014, Metagenomic analysis of bacterial community composition among the cave sediments of IndoBurman biodiversity hotspot region: PeerJ Preprints, 2:e631v1, $30 \mathrm{p}$. doi:10.7287/peerj.preprints.631v1.

Elomari, M., Coroler, L., Verhille, S., Izard, D., and Leclerc, H., 1997, Pseudomonas monteilii sp. nov., isolated from clinical specimens: International Journal of Systematic Bacteriology, v. 47, p. 846-852. doi:10.1099/00207713-47-3-846.

Fleming, T.H., 1988, The Short-Tailed Fruit Bat. A Study in Plant-Animal Interactions: Chicago, The University of Chicago Press, Wildlife Behavior and Ecology Series, $365 \mathrm{pp}$.

Galán, C., and Herrera, F.F., 2006, Fauna cavernícola de Venezuela: una revisión: Boletín de la Sociedad Venezolana de Espeleología, v. 40, p. 3957.

Galán, C., Herrera, F.F., and Rincón, A., 2008, Avance preliminar sobre la fauna cavernícola de la cueva de Los Laureles (Sierra de Perijá, Venezuela): capturas directas, ecología, diversidad y hallazgo de alto número de nuevas especies troglobias: Instituto Venezolano de Investigaciones Científicas, Sociedad Venezolana de Espeleología and Sociedad de Ciencias Aranzadi, Technical Report, 29 p.

Galán, C., Herrera, F.F., Rincón, A., and Leis, M., 2009, Diversidad de la fauna cavernícola de los karsts en caliza del norte de Venezuela: Instituto Venezolano de Investigaciones Científicas, Sociedad Venezolana de Espeleología and Sociedad de Ciencias Aranzadi, Technical Report, 14 p.

Garrity, C.P., Hackley, P.C., and Urbani, F., 2006, Digital geologic map and GIS database of Venezuela. USGS Data Series No. 199. https://pubs.er. usgs.gov/publication/ds199 [accesed on April 01, 2016].

Gerhardt, P., Murray, R.G.E., Wood, W.A., and Krieg, N.R., eds., 1994, Methods for General and Molecular Bacteriology: Washington D.C., American Society for Microbiology, $791 \mathrm{p}$.

González-Quiñones, N., Fermin, G., and Muñoz-Romo, M., 2014, Diversity of bacteria in the sexually selected epaulettes of the little yellow-shouldered bat Sturnira lilium (Chiroptera: Phyllostomidae): Interciencia, v. 39, p. 882-889.

Hall, T.A., 1999, BioEdit: a user-friendly biological sequence alignment editor and analysis program for Windows 95/98/NT: Nucleic Acids Symposium Series, v. 41, p. 95-98.

Handley, C.O., Jr., 1987, New species of mammals from northern South America: fruit-eating bats, genus Artibeus Leach, in Patterson, B.D., and Timm, R.M., eds., Studies in Neotropical Mammalogy: Essays in Honor of Philip Hershkovitz: Field Museum of Natural History, Fieldiana Zoology news series 39, p. 163-172.

Högenauer, C., Langner, C., Beubler, E., Lippe, I.T., Schicho, R., Gorkiewicz, G., Krause, R., Gerstgrasser, N., Krejs, G.J., and Hinterleitner, T.A., 2006, Klebsiella oxytoca as a causative organism of antibiotic-associated hemorrhagic colitis: The New England Journal of Medicine, v. 355, p. 2418-2426. doi:10.1056/NEJMoa054765.

INAMEH, 2008, National Institute of Meteorology and Hydrology of Venezuela: http://www.inameh.gob.ve/.

Jurado, V., Laiz, L., Rodriguez-Nava, V., Boiron, P., Hermosin, B., SanchezMoral, S., and Saiz-Jimenez, C., 2010, Pathogenic and opportunistic microorganisms in caves: International Journal of Speleology, v. 39, p. 15-24. doi:10.5038/1827-806X.39.1.2.

Kim, Ok-Sun, Cho, Yong-Joon, Lee, Kihyun, Yoon, Seok-Hwan, Kim, Mincheol, Na, Hyunsoo, Park, Sang-Cheol, Jeon, Yoon-Seong, Lee, JaeHak, Yi, Hana, Won, Sungho, and Chun, Jongsik, 2012, Introducing EzTaxon-e: a prokaryotic 16S rRNA gene sequence database with phylotypes that represent uncultured species: International Journal of Systematics and Evolutionary Microbiology, v. 62, p. 716-721. doi:10. 1099/ijs.0.038075-0.

Kimura, Z.-I., Chung, Kuung-Mi, Itoh, H., Hiraishi, I., and Okabe, S., 2014, Raoultella electrica sp. nov., isolated from anodic biofilms of a glucosefed microbial fuel cell: International Journal of Systematics and Evolutionary Microbiology, v. 64, p. 1384-1388. doi:10.1099/ijs.0. 058826-0.

Kunz, T.H., Hodgkison, R., and Weise, C., 2009, Methods of capturing and handling bats, in Kunz, T.H., and Parsons, S., eds., Ecological and Behavioral Methods for the Study of Bats second edition: Baltimore, Johns Hopkins University Press, p. 3-35.

Kunz, T.H., and Lumsden, L.F., 2003, Ecology of cavity and foliage roosting bats, in Kunz, T.H., and Fenton, M.B., eds., Bat Ecology: University of Chicago Press, p. 3-89.

Larkin, M.A., Blackshields, G., Brown, N.P., Chenna, R., McGettigan, P.A., McWilliam, H., Valentin, F., Wallace, I.M., Wilm, A., Lopez, R., 
Thompson, J.D., Gibson, T.J., and Higgins, D.G., 2007, Clustal W and Clustal X version 2.0: Bioinformatics, v. 23, p. 2947-2948. doi:10.1093/ bioinformatics/btm 404 .

Linares, O.J., 1987, Murciélagos de Venezuela: Cuadernos Lagoven, Caracas, $119 \mathrm{p}$.

Linares, O.J., 1998, Mamíferos de Venezuela: Sociedad Conservacionista Audubon de Venezuela \& British Petroleum, Caracas, Venezuela, 691 p.

Molina-Chacón, A.J., 1983, Ecología regional de la cuenca alta del río Uribante: contribución a un método para el estudio integral del medio andino venezolano [M.S. Thesis]: Universidad de Los Andes, Mérida, Venezuela, $214 \mathrm{p}$

Muñoz-Romo, M., Ruiz-Ramoni, D., and Ramoni-Perazzi, P., 2014, First record of leucism in the giant fruit-eating bat, Artibeus amplus (Chiroptera: Phyllostomidae): Chiroptera Neotropical, v. 20, p. 13011304.

Murphy, M.E., Goodson, A., Malnick, H., Shah, J., Neelamkavil, R., and Devi, R., 2012, Recurrent Microvirgula aerodenitrificans bacteremia: Journal of Clinical Microbiology, v. 50, p. 2823-2825. doi:10.1128/JCM.00392-12.

Patureau, D., Godon, J.-J., Dabert, P., Bouchez, T., Bernet, N., Delgenes, J.P., and Moletta, R., 1998, Microvirgula aerodenitrificans gen. nov., sp. nov., a new Gram-negative bacterium exhibiting co-respiration of oxygen and nitrogen oxides up to oxygen-saturated conditions: International Journal of Systematic Bacteriology, v. 48, p. 775-782. doi:0.1099/00207713-48-3775.

Pei, A., Oberdorf, W., Nossa, C.W., Agarwal, A., Chokshi, P., Gerz, E.A; Jin, Zhida, Lee, Peng, Yang, Liying, Poles, M., Brown, S.M., Sotero, S., Desantis, T., Brodie, E., Nelson, K., and Pei, Zhiheng, 2010, Diversity of 16S rRNA genes within individual prokaryotic genomes: Applied and Environmental Microbiology, v. 76, p. 3886-3897. doi:10.1128/AEM. 02953-09.

Ramoni-Perazzi, P., Ruiz-Ramoni, D., Muñoz-Romo, M., Thielen Engelbertz, D.R., and Soto-Werschitz, I.A., 2014, Some considerations on the conservation status of the giant fruit-eating bat Artibeus amplus (Phyllostomidae: Stenodermatinae): Interciencia, v. 39, p. 354-356.

Rincón, A.D., 2004, Vertebrados fósiles en cuevas de Venezuela: Cueva Zumbador, un caso excepcional: VII Jornadas Venezolanas de Espeleología, Facultad de Ingeniería, Universidad Central de Venezuela, Caracas (December 3, 2004).

Rogall, T., Flohr, T., and Böttger, E.C., 1990, Differentiation of Mycobacterium species by direct sequencing of amplified DNA: Journal of General Microbiology, v. 136, p. 1915-1920. doi:10.1099/00221287-136-9-1915.

Ruiz-Ramoni, D., 2010, Patrón reproductivo y dieta del murciélago frugívoro, Artibeus amplus (Chiroptera: Phyllostomidae), en una cueva cercana a
Pregonero, Edo. Táchira-Venezuela [Undergrad Thesis]: Universidad de Los Andes, Mérida, Venezuela.

Ruiz-Ramoni, D., Muñoz-Romo, M., Ramoni-Perazzi, P., Aranguren, Y., and Fermin, G., 2011, Folivory in the giant fruit-eating bat Artibeus amplus (Phyllostomidae): a non-seasonal phenomenon: Acta Chiropterologica, v. 13, p. 195-199. doi:10.3161/150811011X578741.

Sambrook, J., and D. Russell, D.W., 2001, Molecular Cloning: a Laboratory Manual: Cold Spring Harbor, New York, Cold Spring Harbor Laboratory Press, 2344 p.

Scheldeman, P., Goossens, K., Rodríguez-Díaz, M., Pil, A., Goris, J., Herman, L., De Vos, P., Logan, N.A., and Heyndrickx, M., 2004, Paenibacillus lactis sp. nov., isolated from raw and heat-treated milk: International Journal of Systematic and Evolutionary Microbiology, v. 54, p. 885-891. doi:10.1099/ijs.0.02822-0.

Sikes, R.S., Gannon, W.L., and the Animal Care and Use Committee of the American Society of Mammalogists., 2011, Guidelines of the American Society of Mammalogists for the use of wild mammals in research: Journal of Mammalogy, v. 92, p. 235-253. doi:10.1644/10-MAMM-F-355.1.

Stackebrandt, E., and Ebers, J., 2006, Taxonomic parameters revisited: tarnished gold standards: Microbiology Today, v. 33, p. 152-155.

Tamura, K., Stecher, G., Peterson, D., Filipski, A., and Kumar, S., 2013, MEGA6: Molecular Evolutionary Genetics Analysis version 6.0: Molecular Biology and Evolution, v. 30, p. 2725-2729. doi:10.1093/molbev/ mst197.

Tschäpe, H., Prager, R., Streckel, W., Fruth, A., Tietze, E., and Böhme, G., 1995, Verotoxinogenic Citrobacter freundii associated with severe gastroenteritis and cases of haemolytic uraemic syndrome in a nursery school: green butter as the infection source: Epidemiology and Infection, v. 114, p. 441-450. doi:10.1017/S0950268800052158.

Urbani, F., Galán, C., and Herrera, F., 2006, 55 años de exploraciones espeleológicas en Venezuela: Boletín de la Sociedad Venezolana de Espeleología, v. 40, p. 17-33.

van der Pijl, L., 1957, The dispersal of plants by bats (Chiropterochory): Acta Botanica Neerlandica, v. 6, p. 291-315. doi:10.1111/j.1438-8677.1957. tb00577.x.

Wang, Qiong, Garrity, G.M., Tiedje, J.M., and Cole, J.R., 2007, Naïve Bayesian classifier for rapid assignment of rRNA sequences into the New Bacterial Taxonomy: Applied and Environmental Microbiology, v. 73, p. 5261-5267. doi:10.1128/AEM.00062-07. doi:10.1128/AEM.00062-07.

Yoh, Myonsun, Matsuyama, J., Ohnishi, M., Takagi, K., Miyagi, H., Mori, K., Park, Kwon-Sam, Ono, T., and Honda, T., 2005, Importance of Providencia species as a major cause of travelers' diarrhea: Journal of Medical Microbiology, v. 54, p. 1077-1082. doi:10.1099/jmm.0.45846-0. 